\title{
Pengembangan LKS Berbasis Pendekatan Rme Untuk Menumbuhkembangkan Kemampuan Berpikir Kritis Matematis Siswa
}

\author{
Nur Atika ${ }^{1}$, Zubaidah Amir MZ2 \\ ${ }^{1,2}$ Program Studi Pendidikan Matematika, UINSultan Syarif KasimRiau \\ Email : 1atika ibnuhajar@yahoo.co.id \\ 2zubaidahmz@yahoo.com
}

\begin{abstract}
ABSTRAK. Penelitian ini bertujuan untuk menghasilkan LKS matematika berbasis pendekatan Realistic Mathematic Education (RME) pada materi pokok segitiga. Penelitian ini dilaksanakan di Sekolah Menengah Pertama Negeri 7 Bengkalis. Model pengembangan yang digunakan adalah ADDIE, yaitu: (A)nalysis, meliputi analisis kurikulum dan analisis kebutuhan; (D)esign, meliputi penyusunan LKS; (D)evelopment, dilakukan pengembangan LKS matematika denganRME; (I)mplementation, dilakukan pada kelompok kecil dan kelompok besar untuk mendapatkan data praktikalitas dan kemampuan berpikir kritis matematis; (E)valuation, dilakukan untuk menganalisis data berdasarkan tahap implementation. Hasil penelitian melalui angket yang dilakukan oleh ahli media adalah 90\%, ahli materi 85,45\%, uji kelompok kecil 90,08\%, uji kelompok besar 89,14\%, dan hasil tes kemampuan berpikir kritis matematis siswa mencapai 84,79\%. Data tersebut menunjukkan bahwa LKS yang dikembangkan layak dan praktis dalam menumbuhkembangkan kemampuan berpikir kritis matematis siswa.
\end{abstract}

Kata kunci: Lembar Kerja Siswa, RME, kemampuan berpikir kritis matematis

\section{PENDAHULUAN}

Sebagai salah satu bidang studi yang terus berkembang dari waktu ke waktu, matematika menjadi lebih bersifat teoritis dan abstrak. Hal inilah yang membuat siswa merasakan bahwa matematika adalah pelajaran yang membosankan dan sulit serta siswa tidak mengetahui dan merasakan manfaat dari matematika itu sendiri.Teori dan konsep yang jarang dikenalkan dalam kehidupan sehari-hari dan jarang digunakanlah yang sering dibahas di bidang studi matematika. Belajar matematika tidak hanya sekedar menghapal rumus saja, tetapi siswa harus berpikir kritis bagaimana cara mendapatkan jawaban sesuai dengan konsep dan langkah-langkah. Berpikir kritis adalah berpikir dengan baik dan merenungkan atau mengkaji tentang proses berpikir orang lain (Surya, 2011). Berpikir kritis merupakan sebuah proses terorganisasi yang memungkinkan siswa mengevaluasi bukti, asumsi, logika, dan bahasa yang mendasari pernyataan orang lain (Johnson, 2011). Berpikir kritis adalah sebuah proses penggunaan kemampuan berpikir secara terarah dan jelas untuk membantu seseorang menyusun, mengevaluasi dan mengaplikasikan keputusan tentang apa yang dipercaya dan dikerjakan (Wijaya, 2012). Keinginan siswa mendapat jawaban dengan rumus praktis akan mengakibatkan rendahnya kemampuan berpikir kritis. Sehingga guru harus bekerja ekstra agar siswa bisa memahami materi dengan baik dengan meningkatkan aktivitas belajar siswa. Selain itu, untuk meningkatkan aktivitas belajar siswa, guru seharusnya memberikan tambahan panduan siswa, yaitu bahan ajar. Bahan ajar yang digunakan dapat mempermudah siswa dalam mempelajari konsep dasar pelajaran. Salah satu bahan ajar adalah berupa Lembar Kerja Siswa (LKS) yang berguna untuk memahami dan memperkuat pemahaman siswa terhadap matematika.Sebagai seorang guru seharusnya memberikan tambahan panduan siswa, yaitu bahan ajar. Salah satunya bahan ajaradalah berupa Lembar Kerja Siswa untuk 
memahami dan memperkuat pemahaman siswa terhadap matematika.Adapun kelebihan dari penggunaan LKS antara lain dapat meningkatkan aktivitas belajar siswa, mendorong siswa mampu bekerja sendiri dan membimbing siswa secara baik ke arah pengembangan konsep (Majid, 2013). Penggunaan LKS ini dapat membuat siswa terlibat aktif dengan materi yang dipelajari dan memberikan pengalaman belajar siswa dalam mengerjakan soal sehingga melatih kemandirian belajar siswa.Dengan adanya LKS, pelaksanaan proses belajar mengajar akan lebih mudah bagi siswa maupun guru. Siswa akan aktif dalam mengerjakan LKS sedangkan guru akan lebih mudah dalam menyampaikan materi kepada siswa.

Realita dilapangan menunjukankan bahwa guru menggunakan bahan ajar dari percetakan yang cenderung berisi kumpulan-kumpulan rumus, soal-soal yang harus dikerjakan siswa dan tidak inovatif sehingga tidak menarik siswa untuk mempelajarinya. Bahan ajar dari percetakan belum memenuhi karakter konstruktivistik dan kurang mendorong siswa dalam memahami materi yang disajikan sehingga belum menumbuhkembangkan kemampuan berpikir kritis matematis siswa. Permasalahan yang sama juga dapat dilihat dari beberapa sekolah seperti pada Sekolah Menengah Pertama Negeri 2 Batu dan Sekolah Menengah Pertama Negeri 19 Malang yang diteliti oleh Qomariah Amanah, Eti Tejo Dwi Cahyowati dan Indriati Nurul Hidayah (Amanah, Cahyowati, Hidayah, 2012) bahwa bahan ajar yang dibeli dari penerbit belum dapat menumbuhkembangkan kemampuan berpikir kritis matematis siswa.Oleh karena itu guru diharapkan berpikir kreatif untuk mengkreasikan bahan ajar siswa yang berkualitas dan cocok serta menarik siswa untuk mempelajarinya sesuai karakteristik siswanya. Seorang guru menambahkan bahan ajar yang menggunakan permasalahan kontekstual sebagai titik awal pembelajaran dan memberikan motivasi kepada siswa untuk belajar matematika dan mengembangkan sendiri ide serta pengalaman yang dimilikinya.

Salah satu pendekatan pembelajaran yang menggunakan masalah kontekstual sebagai titik awal pembelajaran untuk menunjukkan bahwa matematika sebenarnya sangat dekat dengan kehidupan sehari-hari siswa adalah pendekatan Realistic Mathematic Education (RME). Karakteristik RME adalah menggunakan konteks "dunia nyata", model-model, produksi dan konstruksi siswa, interaktif, dan keterkaitan (intertwinment) (Tarigan, 2006). Peran guru terutama sebagai pembimbing dan fasilitator bagi siswa dalam proses rekonstruksi ide dan konsep matematika. De Large (1994) (dalamTarigan, 2006) menggambarkannya sebagai "the art of unteaching" sedangkan Gravemaijer (dalamTarigan, 2006) menjelaskan bahwa peran guru harus berubah dari seorang validator (menyalah/membenarkan) menjadi pembimbing yang menghargai setiap kontribusi (pekerjaan dan jawaban) siswa.

Belajar matematika tidak hanya sekedar menghapal rumus saja, namun melatih siswa agar berpikir kritis bagaimana cara mendapatkan jawaban dari permasalahan yang diberikan. Berpikir kritis merupakan sebuah proses terorganisasi yang memungkinkan siswa mengevaluasi bukti, asumsi, logika, dan bahasa yang mendasari pernyataan orang lain (Johnson, 2011). Berpikir kritis diperlukan dalam kehidupan bermasyarakat, manusia selalu dihadapkan pada permasalahan yang memerlukan pemecahan. Untuk memecahkan suatu masalah tersebut diperlukan data-data agar dapat dibuat keputusan yang logis dan untuk membuat suatu keputusan yang tepat diperlukan kemampuan berpikir kritis yang baik. pengembangan kemampuan berpikir kritis merupakan orientasi pendidikan yang cocok dalam situasi kehidupan yang mengalami perubahan yang cepat. John Dewey mengatakan bahwa sekolah harus mengajarkan cara berpikir yang benar pada anakanak (Johnson, 2011). Oleh karena itu, siswa harus dibekali dengan kemampuan berpikir kritis yang baik dalam menyelesaikan persoalan-persoalan. Desti Haryani mengatakan bahwa salah satu cara dan metode pembelajaran matematika yang dapat membentuk anak berpikir kritis adalah pendekatan Realistic Mathematics Education(Haryani, 2012). Dengan demikian permasalahan yang dibahas dalam penelitian ini adalah bagaimana mengembangkan LKS berbasis RME yang valid dan praktis sehingga dapat menumbuhkembangkan kemampuan berpikir kritis matematis siswa pada submateri segitiga. 


\section{METODE PENELITIAN}

\section{Jenis Penelitian}

Jenis penelitian yang digunakan dalam penelitian ini adalah penelitian pengembangan (Research and Development/R\&D). Research and Development adalah metode penelitian yang digunakan untuk menghasilkan produk tertentu, dan menguji keefektifan produk tersebut (Sugiyono, 2014). Penelitian pengembangan dibidang pendidikan merupakan suatu jenis penelitian yang bertujuan untuk menghasilkan produk-produk untuk kepentingan pendidikan atau pembelajaran yang diawali dengan analisis kebutuhan kemudian dilanjutkan dengan pengembangan produk, setelah itu produk dievaluasi dan diakhiri dengan revisi dan penyebaran produk. Produk yang dihasilkan pada penelitian ini adalah berupa Lembar Kerja Siswa berbasis Pendekatan Realistic Mathematic Education untuk menumbukembangkan kemampuan berpikir kritis matematis siswa. Pada penelitian ini tahap penyebaran produk tidak dilakukan karena keterbatasan biaya dan waktu.

\section{Model Pengembangan}

Model pengembangan yang digunakan adalah model ADDIE, yang terdiri dari lima tahap, yaitu Analysis (analisis), Design (desain), Development (pengembangan), Implementation (implementasi), dan Evaluation (evaluasi) (Pribadi, 2009). Model desain sistem pembelajaran ADDIE dengan komponen-komponennya dapat diperhatikan pada gambar berikut:

$\begin{gathered}\text { Analisis kebutuhan untuk menentukan masalah dan } \\ \text { Analysis }\end{gathered}$
$\begin{gathered}\text { Menentukan kompetensi khusus, metode, bahan ajar, } \\ \text { Design } \\ \text { Developme }\end{gathered}$
Implementa
I

Gambar 1. Model ADDIE

\section{Prosedur Pengembangan}

Pada tahap analysis dilakukan analisis kurikulum dan analisis kebutuhan. Analisis kurikulum dilakukan untuk mengetahui dan mengkaji kurikulum yang berlaku pada sekolah dan untuk menetapkan pada kompetensi yang mana bahan ajar akan dikembangkan. Analisis kebutuhan adalah langkah yang perlu untuk menentukan kemampuan-kemampuan atau kompetensi yang perlu dipelajari oleh siswa untuk menumbuhkembangkan kemampuan berpikir kritis.

Pada tahap design dilakukan penetapan judul LKS yang akan disusun, menyiapkan sumber referensi, melakukan identifikasi terhadap kompetensi dasar serta merancang bentuk kegiatan pembelajaran yang sesuai, mengidentifikasi indikator pencapaian kompetensi dan merancang bentuk dan jenis penelitian yang akan disajikan, dan meracang format penulisan LKS.

Pada tahap developmentdilakukannya pengembangan LKS dengan pendekatan RME untuk menumbuhkembangkan kemampuan berpikir kritis matematis siswa. Produk pengembangan divalidasi oleh validator. Validator yang dimaksud adalah ahli materi pembelajaran dan ahli teknologi pendidikan. Validasi dilakukan oleh dosen dan guru matematika SMP. Uji kevalidan 
dilakukan dengan memberikan angket kepada validator. Masukan dari validator digunakan untuk memperbaiki LKS yang dikembangkan. Tujuan dari validasi ini adalah untuk memeriksa kebenaran materi, tata bahasa dan kepraktisan LKS dalam mencapai tujuan pembelajaran yang ditergetkan dalam LKS.

Setelah melalui tahap validasi, LKS yang dikembangkan diujicobakan kepada siswa. LKS diujicobakan kepada kelas kelompok kecil yang terdiri dari 6 siswa dan kelas kelompok besar dengan jumlah siswa 30 siswa. siswa menggunakan produk dalam pembelajaran matematika dan memberikan penilaian dengan mengisi angket respon siswa. hal ini dilakukan untuk mendapat masukan atau koreksi terhadap produk yang dikembangkan.

Pada tahap evaluation dilakukan untuk mengetahui kelebihan dan kelemahan dari LKS yang telah dikembangkan dan diimplementasikan. Evaluasi adalah sebuah proses pengumpulan data untuk menetukan sejauh mana, dalam hal apa, dan bagian mana tujuan pendidikan sudah tercapai. Jika belum, bagian mana yang belum dan apa sebabnya (Zein dan Darto, 2012).Evaluasi bertujuan untuk menganalisis kelayakan dan kepraktisan LKS yang dikembangkan pada tahap implementasi dan melakukan revisi lanjutan berdasarkan evaluasi pada saat ujicoba lapangan.

\section{Teknik Pengumpulan Data dan Analisis Data}

Teknik pengumpulan data yang digunakan untuk mengevaluasi dan memvalidasi terhadap bahan ajar yang dikembangkan adalah angket dan tes. Teknik analisis data yang digunakan untuk mengolah data hasil pengembangan adalah teknik analisis deskriptif kualitatif dan teknik analisis kuantitatif. Analisis deskriptif kualitatif merupakan suatu teknik pengolahan data yang dilakukan dengan mengelompokkan informasi dari data kualitatif yang berupa masukan, kritik, dan saran perbaikan yang terdapat pada angket. Metode analisis deskriptif kuantitatif adalah suatu cara pengolahan data yang dilakukan dengan cara menyusun secara sistematis dalam bentuk berupa angka-angka dan persentase, mengenai suatu objek yang diteliti, sehingga diperoleh kesimpulan umum. Analisis hasil uji validitas LKS yang dikembangkan dapat dilakukan dengan beberapa langkah, yaitu memberikan skor jawaban dengan kriteria Sangat Baik (skor 5), Baik (skor 4), Cukup Baik (skor 3), Kurang Baik (skor 2), Tidak Baik (skor 1); memberikan nilai persentase dengan rumus:

$$
\text { tingkat validitas }=\frac{\text { skor yang diperoleh }}{\text { skor tertinggi }} \times 100 \%
$$

Kemudian menginterpretasian data berdasarkan tabel berikut:

Tabel 1. Interpretasi Data Validitas LKS berbasis Pendekatan $R M E$

\begin{tabular}{|c|c|c|}
\hline $\mathbf{o}$ & Interval & Kriteria \\
\hline & $81 \%-100 \%$ & Sangat Valid \\
\hline & $61 \%-80 \%$ & Valid \\
\hline & $41 \%-60 \%$ & Cukup Valid \\
\hline & $21 \%-40 \%$ & Kurang Valid \\
\hline & $0 \%-20 \%$ & Tidak Valid \\
\hline
\end{tabular}

Sumber: Riduwan (2012)

Analisis hasil uji praktialitas LKS yang dikembangkan dapat dilakukan dengan beberapa langkah, yaitu memberikan skor jawaban dengan kriteria Sangat Baik (skor 5), Baik (skor 4), Cukup Baik (skor 3), Kurang Baik (skor 2), Tidak Baik (skor 1); memberikan nilai persentase dengan rumus:

$$
\text { tingkat praktikalitas }=\frac{\text { skor yang diperoleh }}{\text { skor tertinggi }} \times 100 \%
$$

Kemudian menginterpretasian data berdasarkan tabel berikut: 
Tabel 2. Interpretasi Data Praktikalitas LKS berbasis Pendekatan RME

\begin{tabular}{|c|c|c|}
\hline o & Interval & Kriteria \\
\hline & $81 \%-100 \%$ & Sangat Valid \\
\hline & $61 \%-80 \%$ & Valid \\
\hline & $41 \%-60 \%$ & Cukup Valid \\
\hline & $21 \%-40 \%$ & Kurang Valid \\
\hline & $0 \%-20 \%$ & Tidak Valid \\
\hline
\end{tabular}

Sumber: Riduwan (2012) dan dimodifikasi

Analisis tes kemampuan berpikir kritis matematis digunakan dengan cara deskriptif kuantitatif. Hasil tabulasi skor yang diperoleh siswa kemudian dicari persentasenya menggunakan rumus:

$$
\mathrm{S}=\frac{\mathrm{R}}{\mathrm{N}} \times 100
$$

Keterangan:

$\mathrm{S}=$ nilai yang diharapkan (dicari)

$\mathrm{R}=$ jumlah skor dari item atu soal yang dijawab benar

$\mathrm{N}=$ skor maksimum dari tes tersebut

Hasil persentase dikategorikan berdasarkan kriteria umum kualifikasi kemampuan berpikir kritis berikut:

Tabel 3. Kriteria Umum Kualifikasi Kemampuan Berpikir Kritis Matematis Siswa

\begin{tabular}{|c|c|c|}
\hline & Interval & Kriteria \\
\hline \multicolumn{3}{|l|}{$\mathbf{o}$} \\
\hline 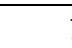 & $81 \%-100 \%$ & Tinggi \\
\hline 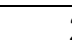 & $61 \%-79 \%$ & Sedang \\
\hline . & $<60 \%$ & Rendah \\
\hline
\end{tabular}

Sumber: Hartono dan Amir (2010)

\section{HASIL PENELITIAN DAN PEMBAHASAN}

Pada tahap analysis, dilakukan analisis kurikulum dan analisis kebutuhan. Berdasarkan analisis kurikulum dan analisis kebutuhan siswa diperoleh LKS yang dikembangkan cocok menggunakan pendekatan RMEyang mampu menghubungkan materi pelajaran yang dirasa abstrak dengan kehidupan nyata yang dekat dengan siswa dan memfasilitasi siswa dalam mengkonstruksikan sendiri pengetahuannya sehingga siswa merasakan kebermaknaan dalam pembelajaran. Pada tahap design dilakukan beberapa desain yaitu mendesain cover, kata pengantar, daftar isi, peta konsep, kegiatan belajar dan karikatur. Pada tahap ini juga menyusun instrumen penilaian LKS yang digunakan sebagai alat ukur kualitas LKS yang dikembangkan.

Tahap selanjutnya adalah development, yaitu mengembangkan LKS matematika submateri segitiga. Kesulitan yang dialami siswa dalam pembelajaran dekontekstual disebabkan karena konsep matematika yang dipelajari tidak bermakna bagi mereka, selain itu siswa juga dituntut dengan cepat mencapai tahap matematika formal. Oleh karena itu dikembangkan materi pada LKS dengan pendekatan RME agar pembelajaran yang diberikan akan terasa bermakna bagi siswa dan siswa dapat mengembangkan idenya sendiri.Di dalam pengembangan LKS dengan pendekatan RME beberapa saran dari dosen pembimbing digunakan dalam pengembangan LKS. 
Setelah selesai, LKS tersebut dinilai oleh ahli teknologi pendidikan dan ahli materi pembelajaran dengan menggunakan angket penilaian LKS. Berikut hasil validitas oleh ahli teknologi pendidikan:

Tabel 4. Hasil Validitas oleh Ahli Teknologi Pendidikan

\begin{tabular}{clrl}
\hline No. & $\begin{array}{c}\text { Indikator Penilaian Validitas } \\
\text { LKS }\end{array}$ & $\begin{array}{c}\text { Nilai } \\
\text { Validitas }\end{array}$ & Kriteria \\
\hline 1 & Teknik Penyajian & $90 \%$ & Sangat Valid \\
\hline 2 & Penggunaan Bahasa dalam LKS & $90 \%$ & Sangat Valid \\
\hline 3 & Komunikatif dan Interaktif & $90 \%$ & Sangat Valid \\
\hline 4 & Tampilan LKS & $90 \%$ & Sangat Valid \\
\hline & Rata-rata & $90 \%$ & Sangat Valid \\
\hline
\end{tabular}

Berdasarkan tabel 4, skor rata-rata penilaian LKS oleh ahli teknologi pendidikan adalah $90 \%$ dengan kriteria sangat validkarena berada pada rentang $81 \%-100 \%$, sehingga LKS matematika sudah layak untuk digunakan. Namun, saran perbaikan dari validator dari ahli dijadikan bahan perbaikan dalam pernyempurnaan LKS ini. Beberapa saran yang diberikan ahli teknologi pendidikan antara lain adalah perbaiki desain cover dan tambahkan judul kegiatan siswa pada setiap kegiatan yang ada di LKS. Berikut hasil validitas oleh ahli materi pembelajaran:

Tabel 5. Hasil Validitas oleh Ahli materi Pembelajaran

\begin{tabular}{clcc}
\hline No. & Indikator Penilaian Validitas LKS & $\begin{array}{c}\text { Nilai } \\
\text { Validitas }\end{array}$ & Kriteria \\
\hline $\mathbf{1}$ & Kesesuaian Materi dengan SK dan KD & $90 \%$ & Sangat Valid \\
\hline $\mathbf{2}$ & Kemutakhiran Materi & $80 \%$ & Sangat Valid \\
\hline $\mathbf{3}$ & Ketercernaan Materi & $86 \%$ & Sangat Valid \\
\hline $\mathbf{4}$ & Karakteristik RME & $86,67 \%$ & Sangat Valid \\
\hline $\mathbf{5}$ & Aspek Bahasa & $80 \%$ & Valid \\
\hline $\mathbf{6}$ & Alokasi Waktu & $80 \%$ & Valid \\
\hline & Rata-rata & $83,78 \%$ & Sangat Valid \\
\hline
\end{tabular}

Berdasarkan tabel 5, skor rata-rata penilain LKS oleh ahli materi pembelajaran 83,78\% dengan kriteria sangat valid karena berada pada rentang 81\% - 100\%. Saran perbaikan yang diberikan ahli materi pembelajaran antara lain adalah perbaiki penggunaan konteks nyata dan tambahkan konteks nyata pada awal materi luas segitiga. Saran yang diberikan ahli direvisi untuk penyempurnaan LKS yang dikembangkan. Berikut hasil penilain secara keseluruhan:

Tabel 6. Hasil Validitas Secara Keseluruhan

\begin{tabular}{clcl}
\hline No. & Indikator Penilaian Validitas LKS & $\begin{array}{c}\text { Nilai } \\
\text { Validitas }\end{array}$ & Kriteria \\
\hline $\mathbf{1}$ & Ahli Teknologi & $90 \%$ & Sangat Valid \\
\hline $\mathbf{2}$ & Ahli Materi Pembelajaran & $83,78 \%$ & Sangat Valid \\
\hline & Rata-rata & $86,89 \%$ & Sangat Valid \\
\hline
\end{tabular}

Berdasarkan tabel 6 rata-rata penilaian LKS oleh ahli teknologi pendidikan dan ahli materi pembelajaran adalah $86,89 \%$ dengan kriteria sangat valid. Oleh karena itu dapat disimpulkan bahwa menurut ahli teknologi pendidikan dan ahli materi pembelajaran, LKS yang dikembangkan telah valid.Setelah LKS matematika yang dikembangkan divalidasi oleh validator, selanjutnya LKS matematika yang dikembangkan diujicobakan kepada dua kelompoksiswa yaitu kelompok kecil dan kelompok besar. Berikut hasil uji coba kelompok kecil: 
Tabel 7. Hasil Analisis Respon Siswa Kelompok Kecil

\begin{tabular}{clcl}
\hline No. & \multicolumn{1}{c}{$\begin{array}{c}\text { Indikator Penilaian Praktikalitas } \\
\text { LKS }\end{array}$} & $\begin{array}{c}\text { Nilai } \\
\text { Praktikalitas }\end{array}$ & Kriteria \\
\hline $\mathbf{1}$ & Sajian/struktur & $91,11 \%$ & Sangat Praktis \\
\hline $\mathbf{2}$ & Penggunaan LKS & $89,22 \%$ & Sangat Praktis \\
\hline $\mathbf{3}$ & Kekonsistenan Materi & $86,67 \%$ & Sangat Praktis \\
\hline $\mathbf{4}$ & Bahasa & $93,33 \%$ & Sangat Praktis \\
\hline \multicolumn{2}{r}{ Rata-rata } & $90,08 \%$ & Sangat Praktis \\
\hline
\end{tabular}

Berdasarkan tabel 7 didapatkan hasil responden dari kelompok kecil sebesar 90,08\% dengan kriteria sangat praktis, namun terdapat beberapa saran perbaikanyang dijadikan bahan pertimbangan dalam penyempurnaan LKS. Saran yang diberikan antara lain bahasa yang digunakan masih sulit dimengerti, adanya gambar yang kurang jelas, keterangan pada materi ada yang kurang jelas.Setelah direvisi berdasarkan saran-saran yang diterima, selanjutnya diujicobakan kepada kelompok besar. Berikut hasil uji coba kelompok besar:

Tabel 8.Hasil Analisis Respon Siswa Kelompok Besar

\begin{tabular}{clcc}
\hline No. & \multicolumn{1}{c}{$\begin{array}{c}\text { Indikator Penilaian Praktikalitas } \\
\text { LKS }\end{array}$} & $\begin{array}{c}\text { Nilai } \\
\text { Praktikalitas }\end{array}$ & Kriteria \\
\hline $\mathbf{1}$ & Sajian/struktur & $86,89 \%$ & Sangat Praktis \\
\hline $\mathbf{2}$ & Penggunaan LKS & $88,35 \%$ & Sangat Praktis \\
\hline $\mathbf{3}$ & Kekonsistenan Materi & $88,33 \%$ & Sangat Praktis \\
\hline $\mathbf{4}$ & Bahasa & $93 \%$ & Sangat Praktis \\
\hline \multicolumn{2}{r}{ Rata-rata } & $89,14 \%$ & Sangat Praktis \\
\hline
\end{tabular}

Berdasarkan tabel 8 didapat hasil responden kelompok besar adalah 89,14\% dengan kriteria sangat praktiskarena berada pada rentang $81 \%$ - 100\%. Pada akhir pertemuan, siswa diberikan posttest berupa soal kemampuan berpikir kritis matematis setelah menggunakan LKS yang dikembangkan. Tingkat efektifitas dapat diketahui dengan membandingkan hasil posttest yang diperoleh siswa dengan nilai KKM. Nilai KKM untuk matematika kelas VII adalah 70. Nilai $\geq 70$ termasuk kategori tuntas dan nilai $<70$ termasuk kategori tidak tuntas. Berikut hasil efektifitas LKS matematika dengan pendekatan RME:

Tabel 9. Hasil Efektifitas LKS Matematika dengan Pendekatan RME

\begin{tabular}{cccc}
\hline No. & Jumlah Siswa & Interval & Kriteria \\
\hline $\mathbf{1}$ & 27 orang & $\geq 70$ & Tuntas \\
\hline $\mathbf{2}$ & 3 orang & $<70$ & Tidak Tuntas \\
\hline & Rata-rata & $84,79 \%$ & Tinggi \\
\hline
\end{tabular}

Berdasarkan tabel 9 terlihat bahwa 27 dari 30 siswa memenuhi kriteria tuntas dalam pembelajaran matematika dengan nilai lebih besar dari 70 (nilai KKM). Presentase rata-rata juga menunjukkan angka 84,79\% yang berarti jauh di atas nilai KKM dan dengan LKS yang dikembangkan, siswa memiliki kemampuan berpikir kritis matematis dengan kategori tinggi.

Tahap terakhir adalah evaluation (evaluasi). Pada tahap ini dilakukan revisi terhadap LKS yang telah dikembangkan. Perbaikan dilakukan berdasarkan hasil penilaian dari validator maupun siswa. semua saran perbaikan yang diberikan terhadap LKS yang dikembangkan direvisi dengan baik.

Penelitian pengembangan LKS berbasis RME ini tidak terlepas dari beberapa keterbatasan. Adapun keterbatasan tersebut antara lain:

1. LKS matematika dengan pendekatan RME ini hanya pada materi segitiga.

2. Uji coba lapangan dilakukan pada satu kelas saja karena keterbatasan biaya dan waktu. 
3. Pertemuan pada pembelajaran dilakukan hanya 4 kali pertemuan, dan ditambah dengan dua pertemuan untuk pretest dan posttest.

4. Praktikalitas dilakukan hanya pada satu kelas tanpa kelas pembanding.

\section{PENUTUP}

\section{Kesimpulan}

Berdasarkan hasil penilaian validator pada setiap aspek di lembar validasi secara keseluruhan dapat disimpulkan bahwa LKS yang dikembangkan menunjukkan persentase berada pada selang $81 \%-100 \%$ yang termasuk kriteria sangat valid. Sementara itu hasil praktikalitas LKS matematika yang dikembangkan menunjukkan persentase berada pada selang $81 \%-100 \%$ yang termasuk kriteria sangat valid. Dan hasil test kemampuan berpikir kritis matematis siswa setelah menggunakan LKS yang dikembangkan menunjukkan persentase pada selang 81\% $100 \%$ yang termasuk kriteria sangat valid. LKS pengembangan ini dapat disimpulkan valid, praktis, dan efektif.

\section{Saran}

Adapun saran pengembangan LKS lebih lanjut adalah sebagai berikut:

1. LKS matematika dengan pendekatan $R M E$ ini dikembangkan lebih lanjut dan mendalam dengan menggunakan kelas pembanding agar kualitas LKS lebih teruji keefektifannya.

2. Bagi peneliti selanjutnya hendaknya mengembangkan LKS dengan pendekatan RME pada materi yang berbeda dan lebih luas lagi.

3. Bagi peneliti selanjutnya hendaklah mengimplementasikan LKS yang dikembangkan di beberapa sekolah.

\section{DAFTAR PUSTAKA}

Amanah, Q danCahyowati, E.T.DdanHidayah, I.N. (2012).Jurnal Online UniversitasNegeri Malang: vol.

PengembanganLembarKerjaSiswaPadaMateriRelasidanFungsidenganPendekatan Realistic

Mathematics Educations (RME) untukSiswaKelas VIII Semester I..

Hartono dan Amir, Z. (2010). Pengaruh Pembelajaran dengan Pendekatan Open-Ended terhadap Kemampuan Berpikir Kreatif Mahasiswa Fakultas Tarbiyah dan Keguruan UIN Sultan Syarif Kasim Riau. Laporan Penelitian [Tidak Diterbitkan]. Lembaga Penelitian dan Pengembangan UIN Sultan Syarif Kasim Riau

Haryani, D. (2012). Prosiding Seminar Nasional Matematika dan Pendidikan Matematika FMIPA UNY. FMIPA UNY.

Johnson, E.B. (2011). Contextual Teaching and Learning: Menjadikan Kegiatan Belajar Mengajar Mengasyikkan dan Bermakna. Bandung : Kaifa.

Majid, A. (2013). Strategi Pembelajaran. Bandung : PT Remaja Rosdakarya.

Pribadi, B.A. (2009). Model Desain Sistem Pembelajaran. Jakarta : PT Dian Rakyat.

Riduwan. (2012). Skala Pengukuran Variabel-variabel Penelitian. Alfabeta: Bandung.

Sugiyono. (2014). Metode Penelitian Pendidikan. Bandung: Al-Fabeta.

Surya, H. (2011). Strategi Jitu Mencapai Kesuksesan Belajar. PT Gramedia: Jakarta.

Tarigan, D. (2006). Pembelajaran Matematika Realistik. Jakarta: Departemen Pendidikan Nasional Direktorat Jenderal Pendidikan Tinggi.

Wijaya, A. (2012). Pendidikan Matematika Realistik: Suatu Alternatif Pendekatan Pembelajaran Matematika. Graha Ilmu: Yogyakarta.

Zein, M dan Darto. (2012). Evaluasi Pembelajaran Matematika. Daulat Riau: Pekanbaru. 